\title{
PENINGKATAN MOTIVASI BELAJAR DAN KEMAMPUAN BERLARI MELALUI MODEL PERMAINAN PERLOMBAAN PADA SISWA KELAS 3 SD NEGERI BANDUNG WONOSEGORO BOYOLALI
}

\author{
Samudi \\ Samudi890@gmail.com \\ SD Negeri Bandung, Wonosegoro, Boyolali
}

\begin{abstract}
ABSTRAK
Tujuan penelitian ini adalah untuk meningkatkan motivasi belajar dan kemampuan berlari pada siswa kelas 3 SD Negeri Bandung Wonosegoro Boyolali tahun pelajaran 2014/2015.Jenis penelitian ini adalah Penelitian Tindakan Kelas (PTK),yang dilakukan dua siklus dengan prosedur penelitian adalah perencanaan tindakan, pengamatan, dan refleksi. Tehnik pengumpulan data menggunakan: observasi, wawancara, dan dokumentasi.Hasil penelitian menunjukkan temuan bahwa model Permainan dan Perlombaan dapat: 1).Meningkatkan motivasi belajar Penjasorkes materi Pola gerak Lokomotor berlatih lari pada siswa kelas 3 SD Negeri Bandung Wonosegoro Boyolali. Persentase kenaikan motivasi belajar siswa sebesar 3,15 (16.44\%) untuk siklus 1 dan2.73 ( 10.62\%) untuk siklus 2, 2) Meningkatkan kemampuan siswa dalamberlari, siswa berusaha menggunakan kemampuan yang dimilikinya untuk memenangkan perlombaan. Persentase kenaikan kemampuan belajar siswa sebesar $10.69 \%$ untuk siklus 1 dan $13.15 \%$ untuk siklus 2. 3) Meningkatkan persentase jumlah siswa yang mencapai ketuntasan belajar minimal (KKM) berikut: pada kondisi awal, persentase pencapaian KKM sebesar25.00\% (8 siswa), pada siklus 1 persentase meningkat menjadi 55.56\% ( 20 siswa), dan siklus 2 persentase jumlah siswa yang mencapai KKM meningkat menjadi $84.37 \%$ (27siswa)
\end{abstract}

Kata kunci: Penjaskes, motivasi belajar, kemampuan lari, model permainan perlombaan.

\section{PENDAHULUAN}

Masih banyaknya permasalahan yang muncul dalam kegiatan belajar mengajar di sekolah, seperti siswa kurang tertarik pada pelajaran, siswa cenderung pasif dalam mengikuti pembelajaran, siswa merasa bosan untuk mengikuti pembelajaran dan sebagainya. Hasil observasi peneliti dan teman sejawat pada pembelajaran Penjasorkes di kelas 3 SD Negeri Bandung Wonosegoro Boyolali mene- mukan sejumlah permasalahan-permasalahan yang terjadi di lapangan bahwa pem-belajaran Penjasorkes dikarenakan proses belajar mengajar masih menggunakan metode pembelajaran yang tidak menarik, monoton, cenderung guru yang aktif sedangkan siswa cenderung pasif cuma sebagai pendengar saja. Kondisi ini berdampak pada rendahnya motivasi belajar siswa dan kemampuan berlari. Dari jumlah 32 siswa kelas 3 SD Negeri Bandung Kecamatan 
Peningkatan Motivasi Belajar Dan Kemampuan Berlari Melalui Model Permainan Perlombaan (Samudi)

Wonosegoro Kabupaten Boyolali terdapat 11siswa (30.56\%) menunjukkan Mengikuti kegiatan pembelajaran dan sebanyak 13 siswa $(40,62 \%)$ menunjukkan tingkat motivasi sedang dalam mengikuti pembelajaran serta terdapat 8 siswa (25.00\%) menunjukkan tingkat motivasi tinggi dalam mengikuti pembelajaran. Sedangkan kemampuan berlari dari 32 siswa terdapat 1 siswa $(3,13 \%)$ mendapat nilai dengan kategori baik sekali, dan terdapat 7 siswa (21.88\%) mendapat nilai dengan kategori baik, 14 siswa $(43.75 \%)$ mendapat nilai dengan kategori cukup serta 10 siswa $(31,25 \%)$ mendapatkan nilai dengan kategori kurang. Dengan demikian sebagian besar siswa kelas 3 SD Negeri Bandung Kecamatan Wonosegoro Kabupaten Boyolali mendapatkan nilai kemampuan berlari masih rendah.

Berdasarkan latar belakang masalah tersebut di atas, maka dalam penelitian ini permasalahan dapat diidentifikas sebagai berikut:1). Penyampaian materi Pola Gerak Lokomotor berlatih lari pada siswa kelas 3 SD N Bandung Wonosegoro Kabupaten Boyolali semester I tahun pelajaran 2014/2015 kurang menarik terhadap siswa sehingga Motivasi belajar masih rendah; 2). Rendahnya Kemampuan belajar Penjasorkes pada materi Pola Gerak Lokomotor berlatih lari pada siswa kelas 3 SD Negeri Bandung Wonosegoro Kabupaten Boyolali tahun pelajaran 2014/2015; 3). Pembelajaran tingkat motivasi rendah dalam Penjasorkes materi Pola Gerak Lokomotor berlatih lari pada siswa kelas 3 SD Negeri Bandung Wonosegoro Kabupaten Boyolali semester I tahun pelajaran 2014/2015 belum menggunakan model pembelajaran yang tepat sehingga pemahaman siswa terhadap konsep masih kurang.

Permasalahan yang hendak dipecahkan dalam PTK ini adalah: 1). Apakah melalui permainan dan perlombaan dapat meningkatkan motivasi belajar siswa kelas 3 SD Negeri Bandung Kecamatan Wonosegoro Kabupaten Boyolali semester I tahun pelajaran 2014/2015?; 2). Apakah melalui permainan dan perlombaan dapat meningkatkan kemampuan berlatih lari pada siswa kelas 3 SD Negeri Bandung Kecamatan Wonosegoro Kabupaten Boyolali semester I tahun pelajaran 2014/2015?

\section{KAJIAN PUSTAKA}

\section{a. Pengertian Motivasi}

Menurut McDonald dalam Hamalik (2009: 173) motivasi merupakan suatu perubahan energi di dalam pribadi seseorang yang ditandai dengan timbulnya efektif dan reaksi untuk mencapai tujuan.Perumusan ini mengandung tiga unsur yang saling berkaitan: (a) Motivasi dimulai dari adanya perubahan energi dalam pribadi; (b) motivasi ditandai dengan timbulnya perasaan (affective arousal); 
(c) Motivasi ditandai oleh reaksi-reaksi untuk mencapai tujuan.

Motivasi merupakan salah satu faktor yang turut menentukan keefektifan pembelajaran. Callahan dan Clark seperti dikutip oleh Mulyasa (2005:112) mengemukakan bahwa motivasi merupakan tenaga pendorong atau penarik yang menyebabkan adanya tingkah laku ke arah suatu tujuan tertentu. Peserta didik akan belajar dengan sungguh-sungguh apabila memiliki motivasi yang tinggi. Dengan kata lain seorang peserta didik akan belajar dengan baik apabila ada faktor pendorongnya (motivasi). Dalam kaitan ini guru dituntut memiliki kemampuan membangkitkan motivasi belajar peserta didik sehingga dapat membentuk kompetensi dan mencapai tujuan belajar.

$\begin{array}{ccc}\text { Dalam } & \text { kegiatan } & \text { belajar, } \\ \text { motivasi dapat dikatakan } & \text { sebagai }\end{array}$ keseluruhan daya penggerak di dalam diri siswa yang menimbulkan kegiatan belajar, yang menjamin kelangsungan dari kegiatan belajar dan yang memberikan arah pada kegiatan belajar, sehingga tujuan yang dikehendaki oleh subyek belajar itu dapat tercapai (Sardiman, 2007:75).

Menurut Yamin (2006: 173) motivasi belajar merupakan daya penggerak psikis dari dalam diri seseorang untuk dapat melakukan kegiatan belajar dan menambah keterampilan dan pengalaman. Motivasi mendorong dan mengarah minat belajar untuk mencapi suatu tujuan. Siswa akan bersungguhsungguh belajar karena termotivasi mencari prestasi, mendapat kedudukan dalam jabatan, menjadi politikus, dan memecahkan masalah.

\section{b. Jenis Motivasi Belajar}

Menurut Yamin (2006:178180) jenis motivasi dalam belajar dibedakan dalam dua jenis, masingmasing merupakan: (1) motivasi ekstrinsik, (2) motivasi instrinsik.

\section{Motivasi Ekstrinsik}

Menurut Djamarah (2002: 35) motivasi ektrinsik merupakan motifmotif yang aktif dan berfungsinya karena adanya perangsang dari luar. Menurut Yamin (2006:178) motivasi ekstrinsik merupakan kegiatan belajar yang tumbuh dari dorongan dan kebutuhan seseorang tidak secara mutlak berhubungan dengan kegiatan belajarnya sendiri.

Berdasarkan pendapat di atas, maka motivasi ini timbul disebabkan oleh dorongan atau rangsangan dari luar. Menurut Winkel dalam Yamin (2006: 179) adapun yang termasuk dalam bentuk motivasi belajar ekstrinsik merupakan sebagai berikut : a). Belajar demi memenuhi kewajiban; b). Belajar demi menghindari hukuman dan ancaman; c). Belajar demi memperoleh hadiah material yang dijanjikan; d). Belajar demi meningkatkan status sosial; e). Belajar demi memperoleh pujian dari orang penting, misalnya guru dan orang tuanya; f). Belajar demi tujuan jabatan 
Peningkatan Motivasi Belajar Dan Kemampuan Berlari Melalui Model Permainan Perlombaan (Samudi)

yang ingin dipegang atau demi memenuhi persyaratan kenaikan jenjang atau golongan administratif.

\section{Motivasi Intrinsik}

Menurut Djamarah (2002: motivasi intriksik merupakan motifmotif yang menjadi aktif atau berfungsinya tidak perlu dirangsang dari luar, karena dalam setiap individu sudah ada dorongan untuk melakukan sesuatu. Menurut Yamin (2006:179) motivasi instrinsik merupakan kegiatan belajar dimulai dan diteruskan, berdasarkan penghayatan sesuatu kebutuhan dan dorongan yang secara mutlak berkaitan dengan aktivitas belajar.

\section{c. Fungsi Motivasi Belajar}

Menurut Sardiman (2007: 84) hasil belajar akan menjadi optimal, kalau ada motivasi. Makin tetap motivasi yang diberikan, akan makin berhasil pula pelajaran itu. Jadi motivasi akan senantiasa menentukan intensitas usaha belajar bagi para siswa. Oleh karena itu, motivasi berfungsi sebagai berikut: 1). Mendorong manusia untuk berbuat, jadi sebagai penggerak atau motor yang melepaskan energi. Motivasi dalam hal ini merupakan motor penggerak dari setiap kegiatan yang akan dikerjakan; 2). Menentukan arah perbuatan, yakni ke arah tujuan yang hendak dicapai. Dengan demikian motivasi dapat memberikan arah dan kegiatan yang harus dikerjakan sesuai dengan rumusan tujuannya; 3). Menyeleksi perbuatan, yakni menentukan perbuatan-perbuatan apa yang harus dikerjakan yang serasi guna mencapai tujuan, dengan menyisihkan perbuatanperbuatan yang tidak bermanfaat agi tujuan tersebut. Seseorang siswa yang menghadapi ujian dengan harapan dapat lulus, tentu akan melakukan kegiatan belajar dan tidak akan mengabiskan waktunya untuk bermain kartu atau membaca komik, sebab tidak serasi dengan tujuan (Sardiman, 2007: $85)$.

Kemudian menurut Oemar Hamalik dalam Yamin (2006: 176-177) dijelaskan bahwa fungsi motivasi dalam belajar, yaitu: 1). Mendorong timbulnya kelakukan atau suatu perbuatan. Tanpa motivasi, maka tidak akan timbul sesuatu perbuatan seperti belajar; 2). Motivasi berfungsi sebagai pengarah. Artinya mengarahkan perbuatan kepencapaian tujuan yang diinginkan.

\section{Kemampuan atau Prestasi Belajar}

Sardiman (2001: 10) mengemukakan suatu rumusan, bahwa belajar sebagai rangkaian kegiatan jiwa-raga, psikofisik menuju ke perkembangan pribadi manusia seutuhnya, yang menyangkut unsur cipta, rasa dan karsa, ranah kognitif, afektif dan psikomotorik.

Menurut Djamarah (2002 : 22) bahwa hakikat dari aktivitas belajar merupakan suatu perubahan yang terjadi dalam diri individu. Perubahan itu nantinya akan mempengaruhi pola 
pikir individu dalam berbuat dan bertindak. Perubahan itu sebagai hasil dari pengalaman individu dalam belajar.

Prestasi pada dasarnya merupakan hasil yang diperoleh dari suatu aktivitas. Sedangkan belajar pada dasarnya merupakan suatu proses yang mengakibatkan perubahan dalam diri individu, yakni perubahan tingkah laku. Dengan demikian, dapat diambil pengertian yang cukup sederhana mengenai hal ini. Prestasi merupakan hasil yang diperoleh berupa kesankesan yang mengakibatkan perubahan dalam diri individu sebagai hasil dari aktivitas dalam belajar (Djamarah, 2002 : 23).

Prestasi belajar merupakan sebuah kalimat yang terdiri dari dua kata, yakni "prestasi" dan "belajar".Antara kata"prestasi" dan "belajar" mempunyai arti yang berbeda. Prestasi merupakan hasil dari suatu kegiatan yang telah dikerjakan, diciptakan, baik secara individual maupun kelompok. Prestasi tidak akan pernah dihasilkan selama seseorang tidak melakukan suatu kegiatan. Dalam kenyataan untuk mendapatkan prestasi tidak semudah yang dibayangkan, tetapi penuh perjuangan dengan berbagai tantangan yang harus dihadapi untuk mencapainya. Hanya dengan keuletan dan optimisme dirilah yang dapat membantu untuk mencapainya. Oleh karena itu wajarlah pencapaian prestasi itu harus dengan jalan keuletan kerja (Djamarah, 2002 : 19).

\section{b. Faktor yang Mempengaruhi} Kemampuan atau Prestasi Belajar Siswa

Hasil atau prestasi belajar yang diperoleh melalui proses pembelajaran, selain ditentukan oleh siswa sebagai subyek belajar dengan berbagai latar belakang, juga dipengaruhi oleh beberapa faktor lain. Menurut Sri Rumini yang dikutip oleh Suyatinah (2000: 71) memaparkan bahwa proses dan hasil belajar dipengaruhi oleh: 1). Faktor internal/dalam diri individu, meliputi: (a) psikis, meliputi kognitif, afektif, psikomotor, campuran, kepribadian, motivasi, perhatian, self disiplin, dan lain-lain; (b) fisik, meliputi indera, anggota badan, tubuh, kelenjar, syaraf, dan lain-lain; 2). Faktor eksternal/lingkungan, meliputi: (a) Sosial/dinamis, meliputi sosial individu (rumah, sekolah, masyarakat); (b) non sosial, meliputi lingkungan alam (cuaca, iklim, suhu), sosial ekonomi, metode belajar, kurikulum, materi, sarana prasarana, dan lain-lain.

Sedangkan menurut Dimyati dan Mudjiono (2002 : 260) hasil belajar siswa dipengaruhi oleh dua faktor yaitu faktor intern dan ekstern. a).Faktor intern meliputi : (1) sikap terhadap belajar, (2) motivasi belajar, (3) konsentrasi belajar (4) kemampuan mengolah bahan ajar, (5) kemampuan menyimpan perolehan hasil belajar, (6) kemampuan menggali hasil belajar 
Peningkatan Motivasi Belajar Dan Kemampuan Berlari Melalui Model Permainan Perlombaan (Samudi)

yang tersimpan, (7) kemampuan berprestasi atau unjuk hasil belajar, (8) rasa percaya diri siswa, (9) intelegensi dan keberhasilan belajar, (10) kebiasan belajar, dan (11) cita-cita siswa. Faktorfaktor intern ini akan menjadi masalah sejauh siswa tidak dapat menghasilkan tindak belajar yang menghasilkan hasil belajar yang lebih baik. b). Faktorfaktor ekstern belajar meliputi : (1) guru sebagai pembina belajar, (2) prasarana dan sarana pembelajaran, (3) kebijakan penilaian, (4) lingkungan sosial siswa di sekolah, (5) kurikulum sekolah. Dari guru sebagai pembelajar maka peranan guru dalam mengatasi masalah-masalah ekstern belajar merupakan prasyarat terlaksananya siswa dapat belajar.

\section{Permainan Perlombaan}

Plato, Aristoteles, Frobel menganggap bermain sebagai kegiatan yang mempunyai nilai praktis. Artinya bermain digunakan sebagai media untuk meningkatkan keterampilan dan kemampuan tertentu pada anak (Tedjasaputra, $2007: 2$ ).

Jadi permainan merupakan kegiatan bermain. Permainan perlombaan dalam berlatih lari merupakan kegiatan permainan dan perlombaan dalam pembelajaran Penjasorkes, oleh karena itu, prinsip pembelajaran yang digunakan merupakan "bermain sambil belajar dan belajar seraya bermain".

Perlombaan merupakan kegiatan untuk mengadu kemampuan antar dua atau lebih sesesorang atau kelompok dalam suatu hal. Perlombaan juga dapat merupakan bagian dari suatu permainan. Oleh karena itu, permainan perlombaan dalam Penjasorkes materi berlatih lari merupakan upaya untuk mendorong semangat belajar siswa dalam proses pembelajaran. Karena melalui perlombaan, siswa akan termotivasi untuk memenangkan permainan tersebut.

\section{Kajian Penelitian yang Relevan}

1). Sulistiono (2012) melakukan penelitian tindakan kelas upaya meningkatkan motivasi dalam pembelajaran belajar gerak dasar lari melalui pendekatan bermain siswa kelas $5 \mathrm{SD}$ Negeri Penerusan Kecamatan Wadas Lintang Kabupaten Wonosobo, menemukan bahwa model pendekatan bermain dapat meningkatkan motivasi belajar gerak dasar lari pada siswa. 2). Penelitian Tindakan Kelas yang dilakukan oleh Joko Triwaluyo (2013), meneliti tentang Upaya Meningkatkan hasil belajar lari sprin melalui permainan hitam hijau pada siswa kelas 6 SD Negeri 2 Badak Kecamatan Belik Kabupaten Pemalang, menemukan bahwa model Permainan dapat meningkatkan hasil belajar siswa. 3) Darmawan Adi Nugroho (2012) meneliti tentang Upaya meningkatkan Kemampuan Gerak Dasar Lokomotor melalui permainan beregu pada siswa kelas 3 SD Negeri 1 Gancang Kecamatan Gumelar Kabupaten Banyumas, menemukan bahwa melalui 
aplikasi permainan beregu dapat meningkatkan kemampuan gerak dasar Lokomotor.

\section{Manfaat Bermain bagi Anak}

Ada beberapa manfaat bermain bagi anak, antara lain: 1). Manfaat Bermain untuk Perkembangan Aspek Motorik Kasar dan Motorik Halus; 2). Manfaat Bermain untuk Perkembangan Aspek Sosial; 3).Manfaat bermain untuk perkembangan aspek emosi; 4). Manfaat Bermain untuk Perkembangan Aspek Kognisi; 5).Manfaat Bermain untuk Mengembangkan Keterampilan Olahraga dan Menari

\section{Pendidikan Jasmani Olahraga dan Kesehatan}

Kegiatan pembelajaran pendidikan jasmani amat berbeda dengan pelaksanan dari pembelajaran mata pelajaran lain. Pendidikan jasmani merupakan pendidikan melalui aktivitas jasmani.Dengan berpartisipasi dalam aktivitas fisik, siswa dapat menguasai keterampilan dan pengetahuan, mengembangkan apresiasi estetis, mengembangkan keterampilan generik serta nilai dan sikap yang positif, dan memperbaiki kondisi fisik untuk mencapai tujuan pendidikan jasmani.

Olahraga merupakan proses sistematik yang berupa segala kegiatan atau usaha yang dapat mendorong mengembangkan, dan membina potensi-potensi jasmaniah dan rohaniah seseorang sebagai perorangan atau anggota masyarakat dalam bentuk permainan, perlombaan/pertandingan, dan kegiatan jasmani yang intensif untuk memperoleh rekreasi, kemenangan, dan prestasi puncak dalam rangka pembentukan manusia seutuhnya yang berkualitas berdasarkan Pancasila (Samsudin, 2008:2).

Pada jenjang Penjasorkes di SD, Penjasorkes merupakan bagian yang integral dari pendidikan secara keseluruhan, bertujuan untuk mengembangkan aspek kebugaran jasmani, keterampilan gerak, keterampilan berpikir kritis, keterampilan sosial, penalaran, stabilitas emosional, tindakan moral, aspek pola hidup sehat dan pengenalan lingkungan bersih melalui aktivitas jasmani, olahraga dan kesehatan terpilih yang direncanakan secara sistematis dalam rangka mencapai tujuan pendidikan nasional (Samsudin, 2008:141).

\section{Tujuan Pendidikan Jasmani Olahraga dan kesehatan}

Tujuan dari pendidikan jasmani olahraga dan kesehatan antara lain:1). Meletakkan landasan karakter yang kuat melalui internalisasi nilai dalam pendidikan jasmani;2). Membangun landasan kepribadian yang kuat, sikap cinta damai, sikap social dan toleransi dalam konteks kemajemukan budaya, etnis dan agama;3). Menumbuhkan kemampuan berfikir kritis melalui tugas-tugas pembelajaran pendidikan jasmani; 4). Mengembangkan sikap sportif, jujur, disiplin, bertanggung jawab, kerjasama, percaya diri, dan demokratis melalui 
Peningkatan Motivasi Belajar Dan Kemampuan Berlari Melalui Model Permainan Perlombaan (Samudi)

berbagai aktivitas jasmani;5). Mengembangkan keterampilan gerak dan keterampilan teknik serta strategi berbagai permainan dan olahraga, aktivitas pengembangan, senam, aktivitas ritmis, akuatik (aktivitas air), dan pendidikan luar kelas;6). Mengembangkan keterampilan pengelolaan diri dalam upaya pengembangan dan pemeliharaan kebugaran jasmani serta pola hidup sehat melalui berbagai aktivitas jasmani;7). Mengembangkan keterampilan untuk menjaga keselamatan diri sendiri dan orang lain;8). Mengetahui dan memahami konsep aktivitas jasmani sebagai informasi untuk mencapai kesehatan, kebugaran dan pola hidup sehat;9). Mampu mengisi waktu luang dengan aktivitas jasmani yang bersifat rekreatif (Samsudin, 2008:3).

\section{Olah Raga Jalan dan Lari}

Olahraga jalan dan lari merupakan beberapa contoh gerak lokomotor. Gerak jalan dan lari dapat disebut gerak lokomotor, karena gerak yang dilakukan oleh olahraga jalan dan lari merupakan gerak berpindah tempat (Eko Harsono, 2010 : 3).

Kemampuan gerak dasar dikategorikan menjadi 3, yaitu (Eko Harsono, 2010 : 4-5): a). Gerak dasar non-lokomotor; b).Gerak dasar lokomotor; c). Gerak dasar manipulatif

Gerak berjalan dan berlari merupakan bagian dari gerak lokomotor.Gerak lokomotor merupakan gerak berpindah tempat. Gerak berjalan dan berlari juga dapat dikombinasikan dengan gerakan yang lain. Misalnya, dengan melompat dan meluncur. Contoh gerak dasar lokomotor kombinasi jalan dan lari, yaitu: (a) Jalan dengan ujung kaki sambil mengangkat lutut kemudian lari; (b) Jalan cepat kemudian lari.

\section{METODE PENELITIAN}

Penelitian Tindakan Kelas (PTK) ini dilakukan di SD Negeri Bandung Kecamatan Wonosegoro, Kabupaten Boyolali pada mata pelajaran Penjasorkes Materi Pola Gerak Lokomotor Berlaih Lari kelas 3 semester 1 tahun pelajaran 2014/2015.Penelitian ini dilaksanakan pada bulan Juli sampai dengan Agustus 2014. Sebelum pelaksanaan penelitian berjalan, terlebih dahulu dipersiapkan berbagai hal yang berkaitan dengan penelitian yaitu penyusunan proposal penelitian, penyusunan instrumen penelitian, pelaksanaan tindakan dalam rangka pengumpulan data, analisis data dan pembahasan hasil penelitian dilanjutkan penyusunan laporan PTK. Waktu pelaksanaan tahap PTK ini adalah sebagai berikut: 1) penyusunan proposal penelitian dilakukan pada bulan Juli tahun 2014; 2) penyusunan Instrumen PTK dilakukan pada Juli minggu ke- 14 tahun 2014; 3) pelaksanaan tindakan siklus I dilakukan pada tanggal 4, 11, 18 Agustus tahun 2014, sedangkan Siklus II dilakukan pada tanggal 25 Aguatus 2014, 1,8 September tahun 2014. Penentuan 
waktu pelaksanaan tindakan ini didasarkan karena pertimbangan urutan pokok bahasan kelas 3 dan kalender pendidikan di SD Negeri Bandung; 4) Analisis data dan pembahasan hasil penelitian dilakukan pada minggu ke-3 bulan September tahun 2014; 5) Penyusunan laporan penelitian dilakukan pada minggu ke-4 bulan September tahun 2014.

Subjek yang dilibatkan dalam penelitian tindakan kelas ini adalah siswa kelas 3 yang berjumlah 32 yaitu 19 laki-laki dan 13 perempuan.Sumber data penelitian tindakan kelas ini meliputi sumber data primer dan sekunder. Sumber data primer berasal dari hasil pengukuran variabel penelitian tindakan kelas berikut: 1) Scor mutivasi belajar siswa pada pelajaran Penjasorkes; 2) Nilai Kemampuan belajar siswa sebagai gambaran dari penguasaan konsep. Sumber data Sekunder berasal dari hasil pengamatan teman sejawat terhadap mutivasi pembelajaran.

Data yang diungkap dalam penelitian dapat dibedakan menjadi tiga jenis, yaitu: fakta, pendapat dan kemampuan. Menurut Suharsimi Arikunto (2006: 223). Sehubungan dengan hal ini, maka teknik yang digunakan untuk mengumpulkan data digunakan metode, yaitu: 1). Observasi untuk mengumpulkan data yang berkaitan dengan fakta di lapangan; 2). Wawancara digunakan untuk mengumpulkan data yang berkaitan dengan pendapat siswa yang diberikan pembelajaran Penjasorkes dengan model permainan dan perlombaan, serta guru kelas yang mengajar atau yang diajak untuk berkolaborasi dalam penelitian tindakan kelas ini; 3). Tes digunakan untuk mengumpulkan data yang berkaitan dengan kemampuan siswa.

Dalam penelitian ini cara yang digunakan untuk mengembangkan validitas dan reliabilitas data penelitian digunakan teknik trianggulasi. Patton (dalam Sutopo, 2006:92) menjelaskan bahwa ada empat macam teknik trianggulasi, yaitu: (1) trianggulasi data (data trianggulation), (2) trianggulsi peneliti (investigator trianggulation), (3) trianggulasi metodologis (methodological trianggulation), dan (4) trianggulasi teoritis (theoritical trianggulation). Dalam penelitian ini trianggulasi yang digunakan adalah: 1) Trianggulasi data atau sumber; 2).Trianggulasi.

Analisis data apabila telah terkumpul, kemudian diklasifikasikan menjadi dua kelompok data, yakni data kuantitatif yang berbentuk angka-angka dan data kualitatif yang dinyatakan dalam kata-kata atau simbol. Data kualitatif yang dinyatakan dalam katakata tersebut disisihkan untuk sementara, karena akan sangat berguna untuk menyertai dan melengkapi gambaran yang diperoleh dari analisis data kuantitatif (Suharsimi Arikunto, 2006: 239-240). 
Peningkatan Motivasi Belajar Dan Kemampuan Berlari Melalui Model Permainan Perlombaan (Samudi)

Data penelitian yang sudah terkumpul dianalisis secara statistik deskriptif kuantitatif dengan persentase skor (Suharsimi Arikunto, 2008: 84). Perhitungan dalam analisis data menghasilkan persentase pencapaian tingkat motivasi belajar dan kemampuan siswa. Proses perbandingan persentase yang dilakukan kemudian diinterpretasikan.

\section{HASIL DAN PEMBAHASAN Deskripsi Hasil Tiap Siklus dan Antar Siklus}

Setelah melakukan analisa terhadap data yang diperoleh dari antar siklus, maka dapat disimpulkan bahwa model permainan perlombaandapat meningkatkan motivasi dan kemampuan belajar siswa pada materi Pola Gerak Lokomotor Berlatih Lari. Berikut ini Tabel motivasi Antar Siklus

Tabel 1 Motivasi Antar Siklus

\begin{tabular}{|l|c|c|}
\hline \multirow{2}{*}{\multicolumn{1}{|c|}{ Pembelajaran }} & \multicolumn{2}{|c|}{ Tingkat Motivasi Belajar Siswa } \\
\cline { 2 - 3 } & Rata-rata & \% Kenaikan \\
\hline Kondisi Awal & 19.16 & - \\
\hline Siklus I & 22.31 & $16.44 \%$ \\
\hline Siklus II & 24.68 & $10.62 \%$ \\
\hline
\end{tabular}

Dari tabel 1 diatas dapat dilihat grafik pada gambar 1.

Pada tabel dan grafik di atas diketahui bahwa nilai motivasi siswa pada Pra Siklus, siklus I, dan Siklus II mengalami kenaikkan. Rata-rata motivasi siswa pada kondisi awal 19.16 sedangkan pada Siklus I 22,31 dan Siklus II 24.68. Rata-rata dari kondisi awal ke Siklus I mengalami peningkatan $16.44 \%$ dan dari Siklius I ke Siklus II mengalami peningkatan $10.62 \%$.

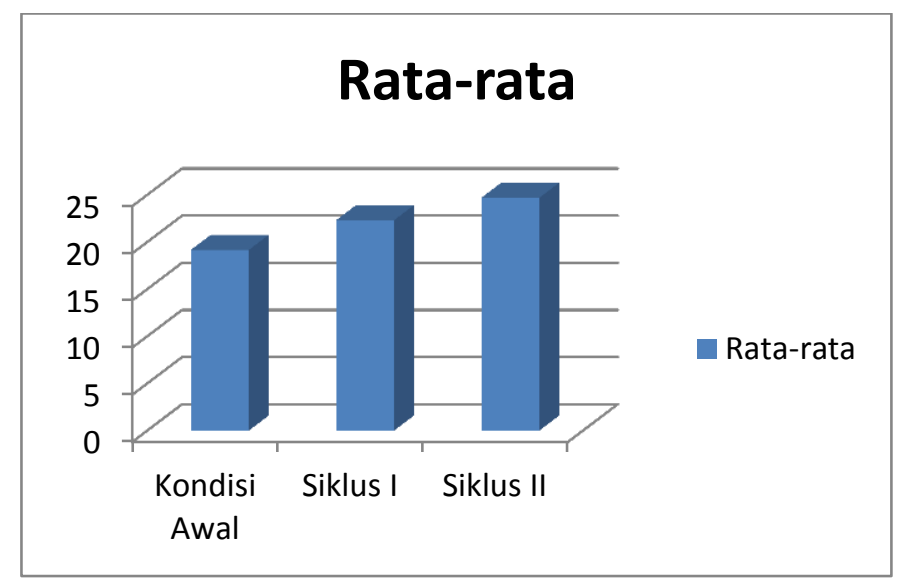

Gambar 1 grafik Motivasi Antar Siklus 
Dengan demikian motivasi Motivasi belajar siswa berdampak pada belajar siswa pada siklus II mengalami peningkatan Kemampuan belajar lari. peningkatan yang cukup besar diban- Berikut tabel Kemampuan belajar lari dingkan dengan pra siklus. Peningkatan antar siklus:

Tabel 2 Nilai Kemampuan Belajar Siswa Antar Siklus

\begin{tabular}{|l|c|c|}
\hline \multirow{2}{*}{\multicolumn{1}{|c|}{ Pembelajaran }} & \multicolumn{2}{c|}{$\begin{array}{c}\text { Tingkat Kemampuan Belajar } \\
\text { Siswa }\end{array}$} \\
\cline { 2 - 3 } & Rata-rata & \% Kenaikan \\
\hline Kondisi Awal & 64.37 & \\
\hline Siklus I & 71.25 & $10.69 \%$ \\
\hline Siklus II & 80.62 & $13.15 \%$ \\
\hline
\end{tabular}

Dari tabel 1 diatas dapat dilihat grafik sebagai berikut:

Dari hasil perbandingan antara Kemampuan pra siklus, Siklus I dan siklus II seperti terlihat pada tabel di atas dan grafik di bawah, diketahui bahwa peningkatan pemahaman siswa pada pelajaran Penjasorkes materi Gerak Lokomotor berlari adalah ratarata Pra Siklus 64.37, Siklus I 71.25 dan Siklus II 80.62. Peningkatan yang dicapai dari Pra Siklus ke Siklus I sebesar 10.69\% dan Siklus I ke Siklus II mengalami peningkatan $13.13 \%$. Dengan demikian, kemampuan belajar siswa pada siklus II mengalami peningkatan yang cukup besar dibandingkan dengan pra siklus dan Siklus I. 


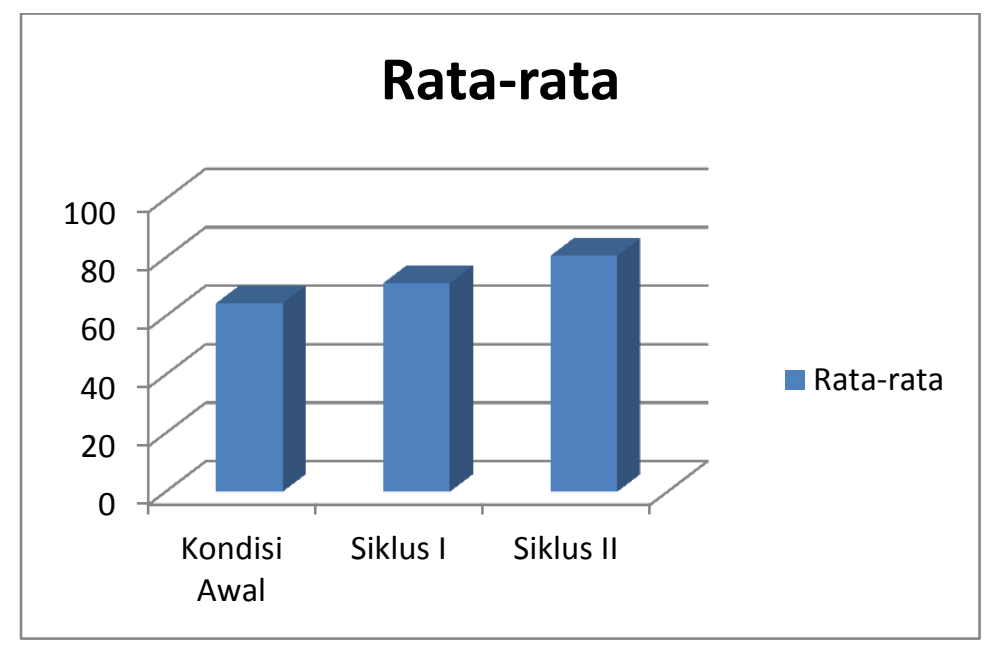

Gambar 2 grafik Nilai kemampuan Belajar Siswa Antar Siklus

\section{Hasil Tindakan dan Pembahasan}

Berdasarkan hasil penelitian seperti yang telah dipaparkan di muka, maka model permainan perlombaan dapat meningkatkan keterlibatan aktif siswa dalam proses pembelajaran, antara lain meningkatkan motivasi belajar siswa, dan meningkatkan hasil belajar siswa kelas 3 SD Negeri Bandung, Wonosegoro Boyolali pada pembelajaran Penjasorkes materi berlatih lari.

Dengan permainan perlombaan, maka suasana pembelajaran Penjasorkes menjadi menyenangkan dan berbeda dari biasanya. Suasana pembelajaran yang menyenangkan ini, membuat siswa menjadi bersemangat mengikuti proses pembelajaran. Siswa berusaha bekerjasama dengan sebaikbaiknya bersama teman kelompoknya untuk memenangkan perlombaan. Siswa berusaha menjaga kekompakkan dengan kelompoknnya dan ingin tampil gemilang bersama kelompoknya untuk menjadi juara, demi nama baik kelompoknya. Upaya yang sungguh-sungguh dari siswa dalam upaya memenangkan perlombaan tersebut, selanjutnya akan mendorong siswa untuk berusaha semaksimal mungkin demi memenangkan perlombaan. Siswa akan mengeluarkan kemampuan yang dimiliki, dan hal ini dapat meningka-tkan hasil belajar siswa dalam berlari.

\section{SIMPULAN DAN SARAN}

\section{Simpulan}

Berdasarkan hasil penelitian dan pembahasan, maka dapat ditarik kesimpulan bahwa:

1. Model permainan perlombaan pada Penjasorkes mampu meningkatkan motivasi belajar siswa selama proses pembelajaran berlangsung. Siswa merasa senang, suasana kelas menjadi kondusif untuk melakukan pembelajaran. Mendorong siswa 
untuk belajar bekerjasama yang bersifat konstruktif, saling bekerjasama, dan menghindari egoisme yang cenderung menonjolkan diri. Besarnya peningkatan dari pra siklus ke siklus 1 16,44\% dan dari siklus 1 ke siklus 2 sebesar $10,62 \%$

2. Model permainan perlombaan pada Penjasorkes mampu meningkatkan kemamapuan siswa dalam berlari. Siswa berusaha menggunakan kemampuan yang dimilikinya untuk memenangkan perlombaan. Sumber belajar tidak terfokus pada guru semata, tetapi didapatkan dari interaksi antar siswa yang ada. Peningkatan yang dicapai dari Pra Siklus ke Siklus I sebesar 10.69\% dan Siklus I ke Siklus II mengalami peningkatan $13.13 \%$.

\section{Saran}

Untuk meningkatkan efektifitas penerapan model permainan perlombaan pada Penjasorkes, perlu ditempuh beberapa hal berikut ini:

1. Pokok bahasan yang diberikan disesuaikan dengan alokasi yang tersedia, sehingga pelaksanaannya tidak mengganggu materi pelajaran yang lain.

2. Pembentukan kelompok ditentukan berdasarkan pertimbangan kemampuan akademik, jenis kelamin dan faktor lain yang dianggap penting, sehingga masing-masing kelompok memiliki kemampuan yang seimbang dan antar siswa dapat saling berinteraksi. 
Peningkatan Motivasi Belajar Dan Kemampuan Berlari Melalui Model Permainan

Perlombaan (Samudi)

\section{DAFTAR PUSTAKA}

Arikunto, Suharsimi, 2006. Prosedur Penelitian: Suatu Pendekatan Praktik. Jakarta: Rineka Cipta.

Arikunto, Suharsimi, Suhardjono, dan Supardi, 2008. Penelitian Tindakan Kelas. Jakarta : Bumi Aksara.

Dimyati \& Mudjiono, 2002. Belajar dan Pembelajaran. Jakarta: Kerjasama Departemen Pendidikan dan Kebudayaan dengan Rineka Cipta.

Eko Harsono \& Muh Marlin, 2010. Gemar Berolahraga untuk Kelas 3 SD dan MI. Jakarta: Pusat Perbukuan, Kementrian Pendidikan Nasional.

Hamalik, Oemar, 2009. Psikologi Belajar dan Mengajar. Bandung: Sinar Baru Algensindo.

Mulyasa, 2005. Menjadi Guru Profesional Menciptakan Pembelajaran Kreatif dan Menyenangkan. Bandung: PT Remaja Rosdakarya.

Ngalim Purwanto, 1990. Psikologi Pendidikan. Jakarta: Pemaja Rosdakarya.

Samsudin, 2008. Pembelajaran Pendidikan Jasmani Olahraga dan Kesehatan. Jakarta: Litera

Sardiman, 2001. Psikologi Pendidikan. Bandung: PT Remaja Rosdakarya.

Susilo, 2007. Panduan Penelitian Tindakan Kelas. Yogyakarta: Pustaka Book Publisher.

Sutopo, H.B., 2006. Metodologi Penelitian Kuanlitatif: Dasar Teori dan Terapannya Dalam Penelitian. Surakarta: Universitas Sebelas Maret.

Suwandi, Sarwiji dan Madyo Ekosusilo, 2007. Modul Pendidikan dan Latihan Profesi Guru (PLPG): Peneltian Tindakan Kelas (PTK) dan Penulisan Karya Ilmiah. Surakarta: Panitia Sertifikasi Guru Rayon 13.

Suyatinah, 2000. Psikologi Perkembangan. Yogyakarta: FIP UNY.

Tedjasaputra, 2007. Bermain, Mainan, dan Permainan. Jakarta: PT Grasindo.

Yamin, Martinis, H. 2006. Sertifikasi Profesi Keguruan di Indonesia. Jakarta: Gang Persada Press. 